Mirosław Chmieliński

Akademia Marynarki Wojennej, 81-127 Gdynia, ul. Śmidowicza 69

\title{
PODSTAWOWE ZASADY DZIAŁAŃ ZABEZPIECZAJĄCYCH PRZEŁADUNEK KONTENERÓW Z MATERIAŁAMI WYBUCHOWYMI W PORTACH MORSKICH I PORTOWYCH TERMINALACH KONTENEROWYCH
}

\begin{abstract}
Streszczenie
Artykuł przedstawia podstawowe zasady dot. działań zabezpieczających podczas przeładunku kontenerów z materiałami wybuchowymi w portach i portowych terminalach kontenerowych. Transport materiałów wybuchowych, ze względu na konieczność zapewnienia bezpieczeństwa ludzi i środowiska, podlega szczególnym rygorom w zakresie jego dopuszczenia do przewozu, doboru opakowania, oznakowania oraz wymagań odnoszących się do kierowcy, środka transportu

i realizacji przewozu.. Działania zabezpieczające obejmują permanentną kontrolę postępowania wszystkich zainteresowanych obrotem kontenerami z materiałami wybuchowymi, zgodnego z szczegółowymi zasadami bezpieczeństwa.

Abstract
The article presents selected issues regarding the principles of organization of security measures during transhipment of containers with explosives in ports and container terminals. Transport of explosives, due to the need to ensure the safety of people and the environment, is subject to special rigors in terms of its admission for transport, selection of packaging, marking and requirements relating to the driver, means of transport. Security measures include permanent control of the behavior of all parties interested in trading in containers with explosives, in accordance with detailed security rules.
\end{abstract}

\section{Wstęp}

Przeładunek kontenerów $\mathrm{z}$ materiałami wybuchowymi $\mathrm{w}$ portach morskich portach i portowych terminalach kontenerowych wymaga zapewnienia określonych warunków zabezpieczenia zewnętrznego będącego wyrazem ostrożności załadowcy w zakresie jego obsługi. Podczas dokonywania manipulacji przeładunkowych materiałów wybuchowych największym zagrożeniem dla przeładowywanego towaru, statku, osób dokonujących przeładunku oraz otoczenia $\mathrm{w}$ strefie zagrożenia jest pożar, który nieopanowany $\mathrm{w}$ zarodku może doprowadzić do wybuchu na statku, w środkach transportu lądowego przed statkiem lub w miejscu postoju tych środków.

Przewóz materiałów wybuchowych jest skomplikowanym procesem wymagającym specjalistycznej wiedzy. Organizacja transportu tych materiałów zgodnie z obowiązującymi przepisami i normami w zakresie bezpieczeństwa, gwarantuje nie tylko zminimalizowanie zagrożeń wynikających z przewozu materiałów wybuchowych, ale i pełną jego efektywność. Możliwość doboru rodzaju opakowania lub środka transportu w zależności od zagrożeń stwarzanych przez konkretny towar niebezpieczny bez pogarszania bezpieczeństwa w przewozie - jest wiedzą wartą poznania i stosowania, gdyż głównym czynnikiem procesu jest stałe ograniczanie zbędnych kosztów [2,4].

Bezpieczeństwo transportu ma dwa komplementarne aspekty: ludzki i materialny. W statystykach większą uwagę przywiązuje się do aspektu ludzkiego wypadków. 
Ich ryzyko jest tym większe, im intensywniejszy jest ruch środków transportu, im gorszy jest stan techniczny tych środków, im gorszy jest stan infrastruktury transportowej, im bardziej nierozsądne jest zachowanie uczestników procesów transportowy. Ryzyko niebezpiecznych zdarzeń istnieje we wszystkich gałęziach transportu, ale jest bardzo zróżnicowane. Z tego powodu, do zabezpieczenia prac związanych z przeładunkiem, postojem środków transportu lądowego oraz morskiego $\mathrm{z}$ materiałami wybuchowymi na terenie portu lub terminala kontenerowego musi być zapewniona asysta przeciwpożarowa, której celem jest nadzorowanie nad prawidłowym przebiegiem przeładunku, postojem środków transportu $\mathrm{z}$ tymi towarami, a w przypadku wystąpienia jakiegokolwiek zagrożenia - spowodowanie jego natychmiastowe usunięcie [2,3].

Przy dokonywaniu oceny zagrożenia wybuchem bierze się pod uwagę najbardziej niekorzystną z punktu widzenia ewentualnych skutków wybuchu sytuację mogącą wytworzyć się $\mathrm{w}$ procesie ich eksploatacji, uwzględniając najbardziej niebezpieczny, występujący tam rodzaj substancji oraz największą jej ilość, jaka mogłaby brać udział w reakcji wybuchu [8].

Od kilkunastu lat można zaobserwować wzrastający popyt na różnego rodzaju materiały niebezpieczne przewożone w transporcie morskim w kontenerach, a równocześnie zapotrzebowanie na znacznie większy tonaż materiałów niebezpiecznych ładowanych na pojedynczy statek.

Kodeks IMDG, czyli Międzynarodowy morski kodeks towarów niebezpiecznych, normuje przewóz ładunków niebezpiecznych w postaci opakowanej drogą morską. Dokument ten został wydany w 1965 r. przez Międzynarodową Organizację Morską (IMO). Zgodnie z przyjętymi ostatnimi poprawkami do Konwencji SOLAS, Kodeks IMDG po raz pierwszy stał się dokumentem obowiązkowym, a nie jak dotychczas, zalecanym przez IMO.

Udział ładunków niebezpiecznych transportowanych drogą morską systematycznie wzrasta. Wiąże się to m.in. ze zwiększającym się przewozu ładunków niebezpiecznych. Ocenia się, że ok. 50\% ogólnej masy ładunków przewożonych morzem zalicza się do niebezpiecznych lub zagrażających środowisku morskiemu. Większość z nich to ładunki masowe, m.in. chemikalia, gazy skroplone, surowce i produkty naftowe oraz ładunki masowe suche [5].

Problem ten o zasięgu międzynarodowym został uregulowany przez Międzynarodową Organizację Morską - IMO, która przedstawiła swój pogląd i zalecenia w dokumencie MSC.1/Circ.1216 z 26.02.2007 stanowiącym skorygowaną wersję uchylonego MSC/Circ.675 z 30.01.1995. Aktualny Cyrkularz, czyli Rekomendacje jest zgodny $\mathrm{z}$ kodeksem IMO, gdzie podkreśla się $\mathrm{W}$ nim znaczenie zapewnienia spokojnego przebiegu prac ładunkowych celem zapobieżenia nieporozumieniom statku z lądem.

rekomendacja ta odróżnia „przejęcie opieki nad towarem”, „keeping”, (jak w przypadku portu i pkp czy portu i statku) od składowania. materiał niebezpiecznych klasy 1 znajdujący się chwilowo na terenie portu morskiego, jako część łańcucha transportowego, nie jest uważany za magazynowanie, gdyż jego obecność jest związana wyłącznie z oczekiwaniem na załadunek i na dalszy przewóz innym rodzajem transportu [7]. magazynowanie, które oznacza przetrzymywanie towarów na czas nieokreślony, nie związane bezpośrednio

z procesem transportu, traktuje się, jako funkcję znajdującą się poza zasięgiem rekomendacji.

na nabrzeżach portów morskich portach i portowych terminalach kontenerowych można dokonywać jedynie bezpośrednich przeładunków kontenerów z materiałami wybuchowymi w łańcuchu transportowym tj. środek transportu lądowego - statek lub statek - środek transportu lądowego według zasad przedstawionych poniżej. 


\section{Problem badawczy i metoda badawcza}

Problem badawczy podejmowany $\mathrm{w}$ artykule określony został poprzez zdefiniowanie i opisanie podstawowych obowiązków uczestników transportu kontenerów $z$ materiałami $\begin{array}{llll}\text { wybuchowymi } & \text { przyczyn } & \text { powstawania } & \text { zagrożenia }\end{array}$ w trakcie przeładunku kontenerów z materiałami wybuchowi, a mogą one być następujące:

- niezgodne $\mathrm{z}$ wymaganiami RID, ADR i IMDG rodzaje i typy opakowań, jednostek ładunkowych, środków transportowych,

- nieodpowiedni stan techniczny opakowań i jednostek ładunkowych, co na skutek nadmiernego zużycia i uszkodzeń nie zapewnia szczelności i umożliwia przedostanie się ładunku do atmosfery,

- brak przygotowania teoretycznego i praktycznego do wykonywania czynności transportowych $\mathrm{z}$ ładunkami niebezpiecznymi w poszczególnych ogniwach łańcucha transportowego,

- niewłaściwa organizacja lub technologia transportu ładunków niebezpiecznych [6].

Z wymienionych powyżej zagrożeń wynika, że obowiązkiem nadrzędnym wszystkich podmiotów, bez względu na ich charakter prawny, zajmujących się transportem i przeładunkiem kontenerów z materiałami wybuchowymi jest zapewnienie wszelkich środków technicznych i organizacyjnych dot. bezpieczeństwa, w zależności od natury i zakresu zagrożeń $\mathrm{w}$ celu zapobiegania zagrożeniom, a w przypadku jego zaistnienia, w celu zminimalizowania jego skutków.

W opinii autora artykułu obowiązkiem podmiotów zajmujących się transportem i przeładunkiem kontenerów $\mathrm{z}$ materiałami wybuchowymi jest powiadomienie służb ratowniczych $\mathrm{W}$ przypadku zaistnienia bezpośredniego zagrożenia podczas przewozu i przeładunku kontenerów z materiałami wybuchowymi oraz udostępnienie im wszelkich informacji potrzebnych do prowadzenia działań ratowniczych.

Podczas przeprowadzania badań zastosowano metodę obserwacyjną, jako jedną z najstarszych metod badawczych, która polegała na rejestracji określonych faktów i ujmowaniu ich we wzajemnych związkach i zależnościach (Rys.1). Zgromadzone dane poddawane zostały interpretacji, jako zjawiska oddziałujące na elementy i procesy danego systemu czy też określonej struktury organizacyjnej. Pozwoliły na zawężenie problematyki $\mathrm{w}$ danym problemie badawczym. Jest to proces ciągły i celowy.

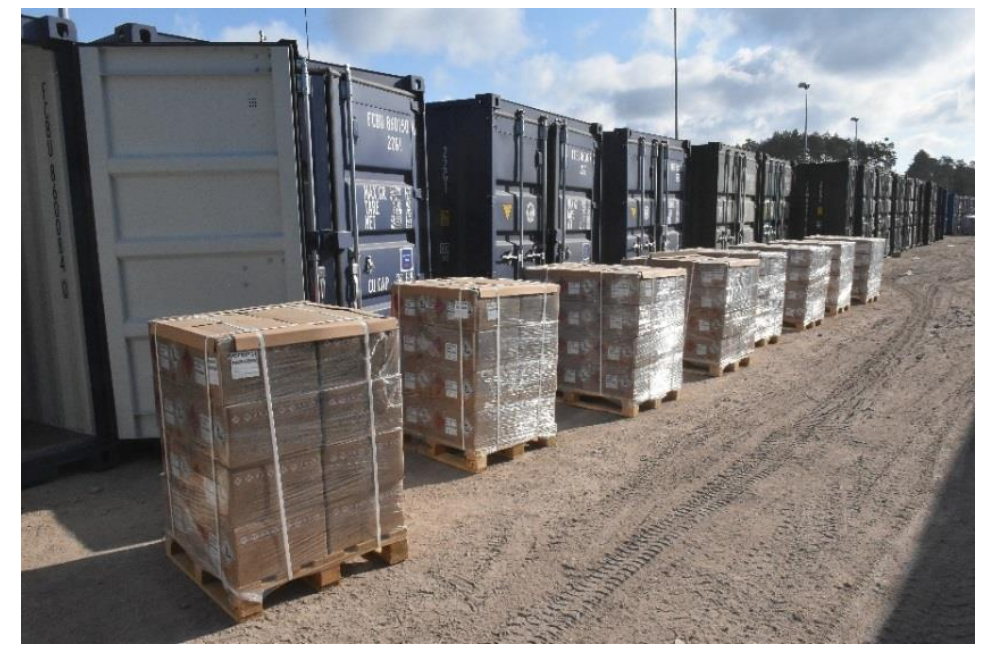

Rys. 1. Palety z materiałami wybuchowymi przygotowane do załadunku do kontenerów. Źródło: Archiwum foto archiwum autora. 
Ponadto wykorzystano eksperymentalną metodę badawczą, która polegała na celowym wprowadzenia do procesu badawczego czynnika eksperymentalnego oraz obserwacji zmian, jakie powstaną pod jego wpływem. Zmiany te stanowią zmienne zależne od zmiennej eksperymentalnej. W metodzie tej ważne było, aby przede wszystkim wybrać odpowiedni czynnik eksperymentalny, ustalić prawdopodobny kierunek zmian, eksperymentalnie zweryfikować hipotezę roboczą, obserwować i rejestrować zmienne zależne.

Zabezpieczenie załadunku kontenerów z materiałami wybuchowymi na statek w porcie morskim lub portowym terminalu kontenerowym należy przeprowadzić zgodnie z zatwierdzoną przez Urząd Morski „Instrukcja technologiczna przeładunku materiałów wybuchowych $w$ porcie morskim" oraz planem ochrony obiektu portowego $\mathrm{z}$ zachowaniem wymogów zawartych

$\mathrm{w}$ aktualnym kodeksie IMDG oraz $\mathrm{w}$,Revised recommendations on the safe transport of dangerous cargoes and related activities in port areas MSC.1 /Circ.1216, 26 February 2007 $[1,9]$.

Prawidłowe stosowanie zasad dotyczących transportu i obsługi kontenerów $\mathrm{z}$ materiałami wybuchowi i przestrzeganie ich $\mathrm{w}$ trakcie pracy zależy $\mathrm{w}$ dużej mierze od uświadomienia wszystkich osób związanych $z$ przeładunkiem o źródłach i rodzaju zagrożenia, a także od dokładnego zrozumienia przepisów (Rys.2). Powinno być to osiągane przez prowadzenie prawidłowo zaplanowanego okresowego szkolenia $\mathrm{w}$ zakresie bezpiecznego postępowania przy manipulacji kontenerów z materiałami wybuchowi.

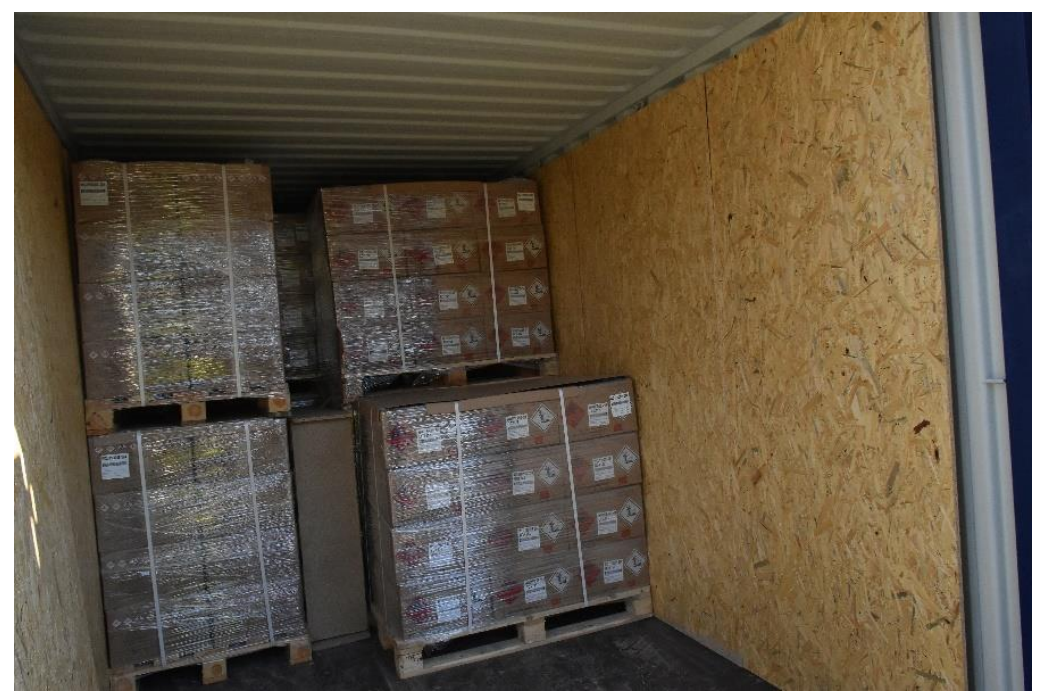

Rys. 2. Palety z materiałami wybuchowymi po załadunku do kontenera. Źródło: Archiwum foto archiwum autora.

Obowiązująca tematyka szkolenia i inne szczegóły z tym związane są zostały zaprezentowane w Rozdziale 1.3 i 1.4 IMDG, a także w przepisach ADR i RID. Obowiązkowym szkoleniom powinni podlegać pracownicy wykonujący następujące czynności:

- przetaczanie i manewrowanie kontenerami z materiałami wybuchowi (CTU - Cargo Transport Unit - oznacza kontener transportowy (uniwersalny i zbiornikowy),

- rozładunek wagonów i samochodów z CTU, rozładunek i załadunek CTU na statek: (sztauerzy, brygadziści, operatorzy sprzętu zmechanizowanego, dźwignicowi),

- usuwanie zanieczyszczeń i rozsypanych pozostałości materiałów niebezpiecznych klasy 1 w przypadku uszkodzenia CTU,

- naprawa uszkodzonych opakowań za zgodą i pod nadzorem rzeczoznawcy. 
Ponadto szkoleniom powinni podlegać wszyscy pracownicy nadzoru tj.: kierownik komórki organizacyjnej odpowiedzialny za eksploatację, służba BHP, gospodarz nabrzeża koordynator przeładunków, starsi brygadziści, kierownik manewrów (ustawiacz) taboru kolejowego, przedstawiciele gestora ładunku.

Szkolenie takie ma na celu zapoznanie pracowników ze stosownymi przepisami, odpowiednie przygotowanie do właściwego postępowania w wypadku sytuacji awaryjnych oraz opanowanie umiejętności rozpoznawania zagrożeń stwarzanych przez kontenery z materiałami wybuchowi [9].

Przyjmuje się następującą formę szkolenia, odpowiednio do zakresu odpowiedzialności i obowiązków osoby, której dotyczy. Pracownicy portu lub terminala kontenerowego powinni być zaznajomieni $\mathrm{z}$ ogólnymi wymaganiami zawartymi $\mathrm{w}$ przepisach o przewozie towarów niebezpiecznych - RID , ADR oraz IMDG.

Osoby, które zatrudnione są przy przeładunku materiałów niebezpiecznych powinny być przeszkolone oraz muszą posiadać uprawnienia do obsługi ładunków niebezpiecznych zgodnie z obowiązującymi przepisami i powinni być kierowani pracownicy posiadający aktualne uprawnienia w tym zakresie, potwierdzone świadectwem ukończenia szkolenia.

Pracownicy przeładunkowi (dokerzy) powinni ukończyć szkolenie w zakresie przeładunku materiałów niebezpiecznych i zasad ppoż., odnawiane co 5 lat. Zakres szkolenia powinien obejmować własności materiałów niebezpiecznych, zasady bezpiecznego przeładunku, zasady postępowania w sytuacjach awaryjnych, zasady postępowania ppoż. Czas trwania szkolenia, wraz z egzaminem ok. 16 godzin lekcyjnych (x45 min).Pracownicy nadzoru powinni ukończyć szkolenie, jak wyżej ze szczególnym uwzględnieniem znajomości aktualnej Instrukcji... dotyczącej zasad obsługi ładunków niebezpiecznych na terenie portu morskiego odnawiane co 3 lata. Plan szkolenia zatwierdza kierujący zakładem, lub osoba przez niego upoważniona. Niezależnie od przebytych szkoleń, pracownicy powinni zapoznać się z aktualną instrukcja dotyczącą zasad obsługi ładunków niebezpiecznych. Szkolenie określone powyżej może zostać zorganizowane przez zakład pracy, z udziałem w charakterze wykładowców specjalistów spoza zakładu pracy w razie potrzeby, lub jego zorganizowanie może zostać zlecone upoważnionemu w tym zakresie podmiotowi zewnętrznemu. Szkolenie powinno zakończyć się egzaminem. Świadectwa pozostają w aktach osobowych każdego pracownika podlegającego przeszkoleniom. Każdorazowo przed rozpoczęciem czynności związanych $\mathrm{z}$ obsługą materiałów niebezpiecznych pracownicy powinni przejść tzw. szkolenie stanowiskowe obejmujące tematykę związaną z pracą z materiałami niebezpiecznymi. Szkolenie powinno być prowadzone przez rzeczoznawcę przy udziale służb BHP portów morskich lub portowych terminalach kontenerowych.

Drogą morską przewożone są największe $\mathrm{z}$ nich, a szczególnym wyzwaniem $\mathrm{w}$ tym zakresie jest wprowadzenie takiego ładunku na pokład statku lub barki (Rys.3). 


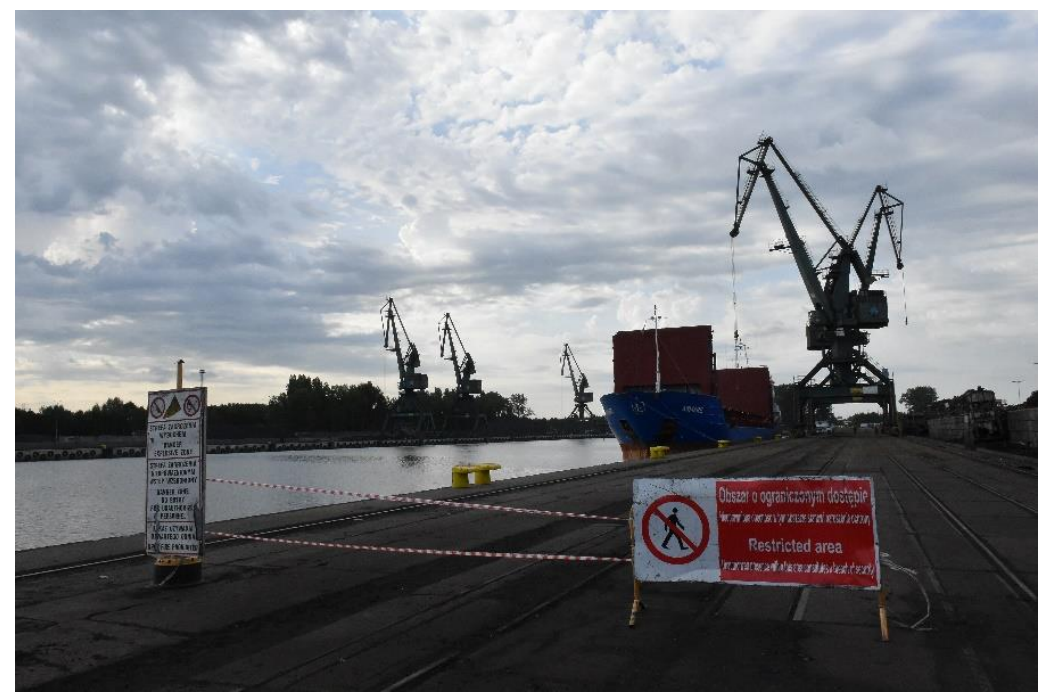

Rys. 3. Statek przy nabrzeżu portowym przygotowany do załadunku materiałów wybuchowych. Źródło: Archiwum foto archiwum autora.

Międzynarodowy transport towarów ponadwymiarowych jest jednym z najtrudniejszych rodzajów transportu (Rys.3-4). Masa i wymiary, wliczając pojazd transportujący, przekraczające poniższe parametry należy zaliczyć do kategorii towaru ponadwymiarowego.

Zabezpieczenia stanowisk pracy związanych $\mathrm{z}$ procesem technologicznym polega miedzy innymi na odpowiednim oznakowaniu stanowiska przeładunkowego i jego wyposażeniu w:

1) sprzęt technologiczny do przeładunku - według potrzeb;

2) podręczny sprzęt przeciwpożarowy - według potrzeb;

3) tablice o zakazie wstępu i przebywania osób postronnych;

4) znaki ostrzegawcze i zakazu. Znaki i tablice właściwe dla przeładowywanych kontenerów z materiałami niebezpiecznymi należy ustawić na wszystkich wejściach i podejściach do stanowiska przeładunkowego w odległości określającej strefę ochronną (Rys.4);

5) tablice informujące należy ustawić w widocznym miejscu, wyznaczonym przez Kierownika terminala;

6) inne zabezpieczenie - według potrzeb;

7) środki pierwszej pomocy - według Karty charakterystyk materiałów niebezpiecznych.

8) Kartę Charakterystyki Materiałów Niebezpiecznych.

Stanowiskami bezpośrednio realizującymi zadania i czynności podczas przeładunku kontenerów z materiałami wybuchowymi są:

1. Kierownik komórki organizacyjnej odpowiedzialny za eksploatację wyznaczonego terenu portowego organizuje i zabezpiecza:

a) siły i środki ochrony przeciwpożarowej do asysty przeciwpożarowej oraz specjalistyczną uzbrojona formację ochronną do ochrony fizycznej przez uzbrojonych wartowników miejsc wyczekiwania środków transportu lądowego, stanowiska przeładunkowego, operacji przeładunkowych i drogi dowozu towaru pod statek na czas przeładunku kontenerów z materiałami niebezpiecznymi;

b) wyznacza gospodarza nabrzeża, który pełni funkcje koordynatora wszystkich czynności związanych z obsługą kontenerów z materiałami niebezpiecznymi;

c) podejmuje decyzję o pracy w warunkach nocnych i w warunkach złej pogody; 
d) wydaje polecenie służbom technicznym do kontroli stanu urządzeń przeładunkowych przed podjęciem przeładunku kontenerów z materiałami niebezpiecznymi.

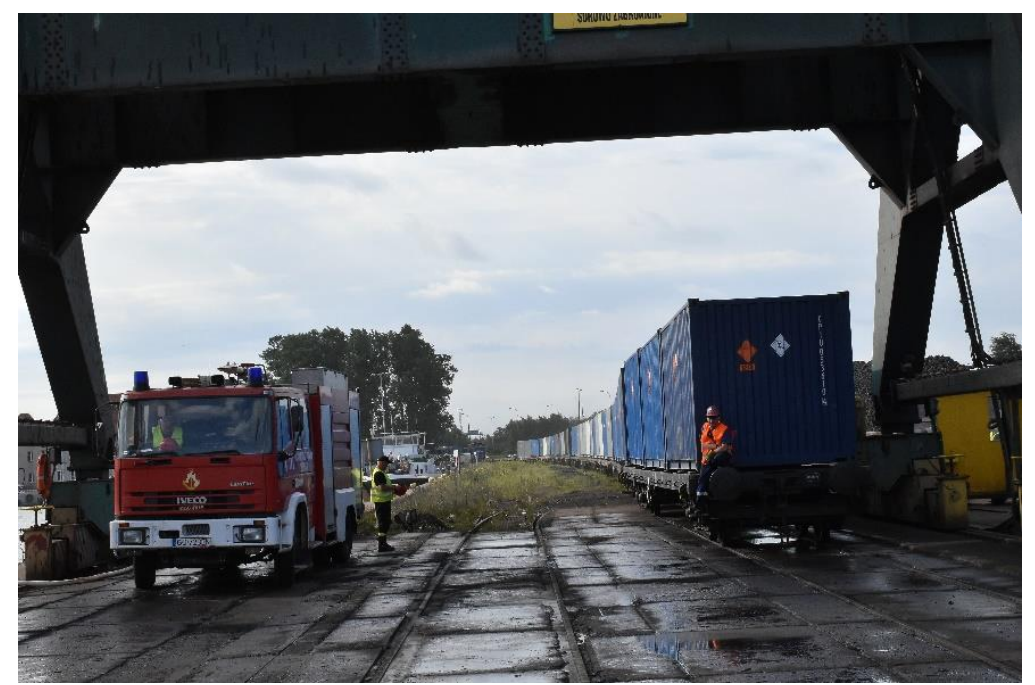

Rys. 4. Transport kolejowy $\mathrm{z}$ kontenerami $\mathrm{z}$ materiałami wybuchowymi i zabezpieczeniem ppoż. na stanowisku przeładunkowym. Źródło: Archiwum foto archiwum autora.

2. Gospodarz Nabrzeża:

a) odpowiada za wszystkie czynności związane z przeładunkiem kontenerów $\mathrm{z}$ materiałami niebezpiecznymi;

b) ma prawo wydawania poleceń wszystkim uczestnikom prac podczas transportu i przeładunku kontenerów z materiałami niebezpiecznymi;

c) nadzoruje zabezpieczenie prac przeładunkowych przy nabrzeżu;

d) występuje do Kapitana Portu o zezwolenie na rozpoczęcie przeładunku po uprzednim uzyskaniu od doradcy pozytywnej opinii i zgody na przeładunek;

e) razem z doradcą, brygadzistą przy współudziale Oficera ochrony obiektu portowego ustalają z dowództwem statku:

- miejsce załadunku na statku

- sposób sztauowania i mocowania,

- przewidywany materiał sztauerski,

- sposób komunikowania się z terminalem oraz procedury powiadamiania służb $\begin{array}{llll}\text { ratowniczych } & 0 & \text { stwierdzonych } & \text { zagrożeniach }\end{array}$ i wypadkach,

- wspólnie z Dowódcą asysty ppoż. potwierdzają środki zabezpieczenia ppoż. statku,

f) uzgadnia z doradcą zakres zastosowania konkretnego sprzętu;

g) odpowiada za każdorazowe przekazywanie „Karty charakterystyki substancji niebezpiecznej i preparatu niebezpiecznego" jednostce ochrony przeciwpożarowej pełniącej służbę asystencyjną, jednostce ochrony fizycznej lub innym jednostkom ratowniczym oraz Kapitanowi Portu;

h) zobowiązuje pracowników nadzoru i kierownictwa PGE S.A., w tym firm zewnętrznych podległych im pracowników biorących udział w przeładunku kontenerów $\mathrm{z}$ materiałami niebezpiecznymi do zapoznania z ww. kartami.

3. Natomiast brygadzista na nabrzeżu kieruje pracami przeładunku kontenerów z materiałami niebezpiecznymi na nabrzeżu. 
4. Ponadto Stużba BHP w portach morskich portach $i$ portowych terminalach kontenerowych:

a) przeprowadza instruktaż wstępny ogólny BHP;

b) W związku z prowadzeniem szkoleń okresowych z zakresu BHP upoważniających pracowników do wykonywania prac przeładunkowych kontenerów z materiałami niebezpiecznymi przez firmę ,zewnętrzną”, a są za nie odpowiedzialne kadry w portach morskich portach i portowych terminalach kontenerowych i prowadzą rejestr szkoleń i kierują pracowników na szkolenia.

5. Oficer Ochrony Obiektu Portowego:

a) jest osobą wyznaczoną do nadzoru i wsparcia działania asysty przeciwpożarowej oraz służby ochrony podczas przeładunku kontenerów z materiałami niebezpiecznymi;

b) podczas przeładunku kontenerów $\mathrm{z}$ materiałami niebezpiecznymi Oficer ochrony obiektu portowego jest cały czas dostępny dla asysty przeciwpożarowej oraz służby ochrony;

c) wyznacza bezpieczne miejsce do parkowania pojazdów z kontenerami z materiałami niebezpiecznymi;

d) wspólnie $\mathrm{z}$ doradcą wyznacza miejsca niezwłocznego odstawienia wagonu lub pojazdu drogowego z uszkodzonym kontenerem z materiałami niebezpiecznymi;

e) wyznacza miejsce ewakuacji dla pojazdów drogowych na wypadek zagrożenia pożarem.

6. Slużby techniczne - brygadzista techniczny w portach morskich portach i portowych terminalach kontenerowych:

a) sprawdza urządzenia, sprzęt i wyposażenie do przeładunku kontenerów z materiałami niebezpiecznymi;

b) kontroluje dźwigi stacjonarne i ich wyposażenie oraz układarki elektryczne, których widły są zabezpieczone materiałem nieiskrzącym.

7. Ganki ladunkowe - sztauerzy:

a) miejsce pracy - ładownia statku, nabrzeże;

b) wykonanie prac sztauerskich zgodnie $\mathrm{z}$ ustalonym planem i wymaganiami bezpieczeństwa pracy;

c) prowadzą mocowanie kontenerów z materiałami niebezpiecznymi na bieżąco.

8. Operatorzy dźwigów nabrzeżowych $i$ innych urządzeń przeładunkowych i transportowych kontenerów z materiałami niebezpiecznymi zajmują swoje miejsca pracy i wykonują czynności związane z przeładunkiem (Rys.5). 


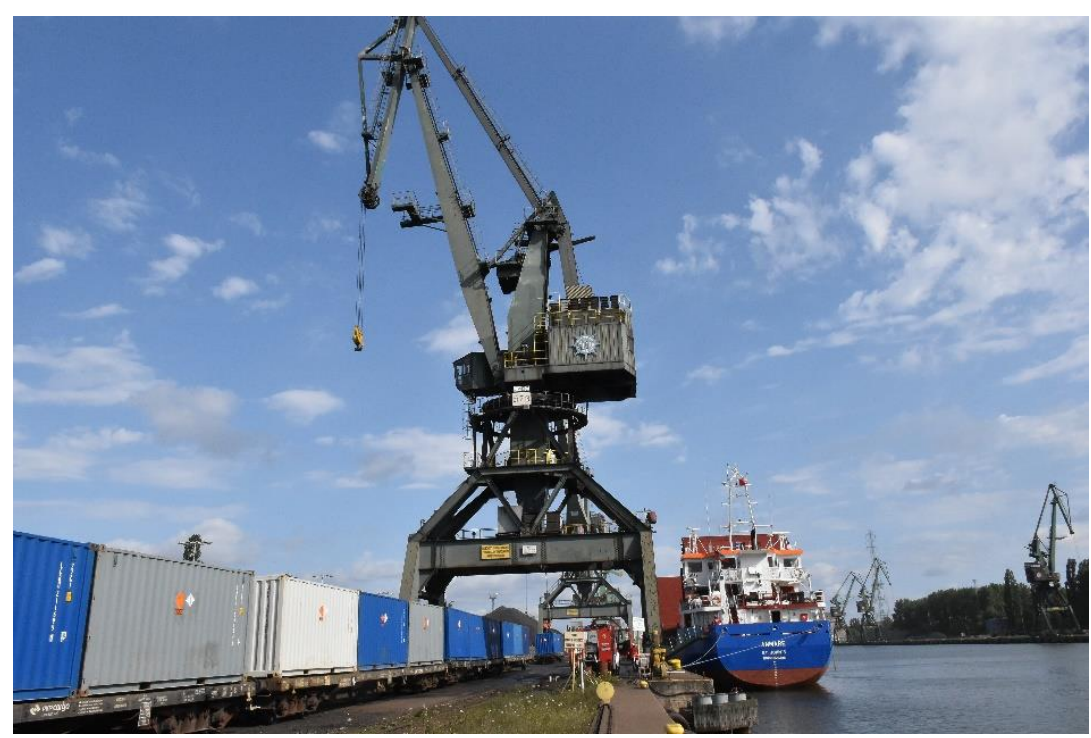

Rys. 5. Statek przy nabrzeżu portowym i kontenery z materiałami wybuchowymi. Źródło: Archiwum foto archiwum autora.

9. Ustawiacz bocznicy kieruje pracami manewrowymi wykonywanymi przez podległych pracowników, a do obowiązków ustawiacza bocznicy w zakresie transportu kolejowego należy:

a) kierowanie pracą manewrową $\mathrm{w}$ zgodzie $\mathrm{z}$ wymogami Regulaminu Pracy bocznicy Basenu Górniczego, instrukcją prowadzenia ruchu kolejowego i zasadami BHP,

b) układanie drogi przebiegu przy rozjazdach ręcznych na terenie bocznicy,

c) dopilnowanie zabezpieczenia taboru na torze przed zbiegnięciem,

d) dopilnowanie aby sprzęgi śrubowe i węże hamulcowe były podwieszone na wspornikach,

e) $\mathrm{W}$ razie wypadku $\mathrm{z}$ pracownikiem podczas wykonywania manewrów powinien natychmiast zawiadomić koordynatora przeładunku kontenerów z materiałami niebezpiecznymi.

10. Doradcy do spraw bezpieczeństwa przewozu towarów niebezpiecznych IMDG / RID / AD:

a) nadzorują transport kontenerów z materiałami niebezpiecznymi koleją lub drogą lądową przed wprowadzeniem na terminal jak i na obszarze portów morskich i portowych terminalów kontenerowych (Rys.6);

b) nadzorują zabezpieczenie prac przeładunkowych przy nabrzeżu;

c) nadzorują prace przeładunkowe, sztauerkę, mocowanie ładunku;

d) decydują o sposobie postępowania z kontenerami uszkodzonymi, nieszczelnymi. 


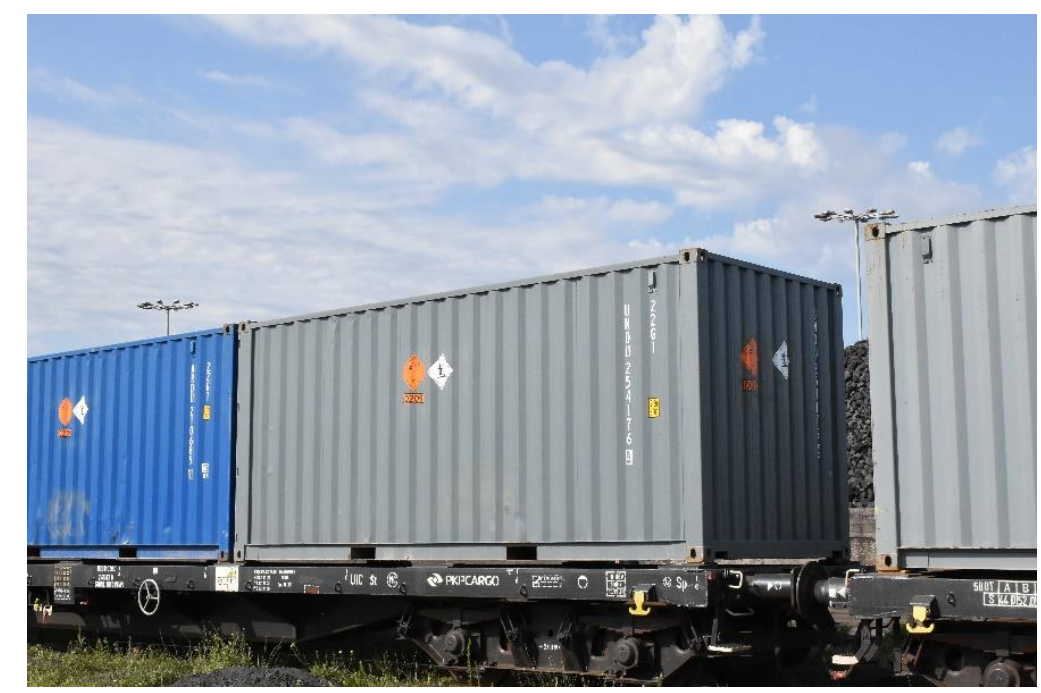

Rys. 6. Oznakowanie kontenerów z materiałami wybuchowymi.

Źródło: Archiwum foto archiwum autora.

Należy przyjąć i uznać, że operacja przeładunkowa kontenerów z materiałami wybuchowymi w porcie jest jednym z elementów łańcucha transportowego, który rozpoczyna się u producenta towaru niebezpiecznego poprzez transport wewnątrz zakładowy, a następnie drogowy lub kolejowy (zgodnie z przepisami ADR i RID) do miejsca przeładunku na statek.

W związku z tym, że operacja przeładunkowa w wyznaczonym miejscu - na terenie portów morskich lub portowych terminalach kontenerowych wiąże się $\mathrm{z}$ tymczasowym zgromadzeniem kontenerów z materiałami wybuchowymi jest określenie stref bezpieczeństwa dla istotnych elementów infrastruktury portu i jego otoczenia [14].

\section{Określenie stref zagrożenia materiałów wybuchowych w portach morskich i portowych terminalach kontenerowych}

Aktualnie obowiązujący w Polsce stan prawny nie reguluje kwestii wyznaczania $\mathrm{w}$ portach morskich stref bezpieczeństwa związanych $\mathrm{z}$ operacjami przeładunkowymi $\begin{array}{lllll}\text { kontenerów } & \mathrm{z} & \text { materiałami wybuchowymi, } & \mathrm{w} & \text { związku }\end{array}$ z powyższym, jako akt prawny stanowiący podstawę określenia stref zagrożeń i minimalnych dopuszczalnych odległości (stref bezpieczeństwa) przyjmuje się Rozporządzenie Ministra Gospodarki, Pracy i Polityki Społecznej z dnia 9 lipca 2003 w sprawie bezpieczeństwa $i$ higieny pracy przy produkcji, transporcie wewnatrzzakładowym oraz obrocie materiałów wybuchowych, w tym wyrobów pirotechnicznych (Dz. U. Nr 163, poz. 1577) oraz inne rekomendacje, w tym Raport Grupy Roboczej IMO (Dangerous Cargoes In Ports International Navigation Association - Report of IMO Working Group 35/2000) [2,15].

Nie podlega rozważaniu ustalenie stref bezpieczeństwa dla środka transportu wodnego, jakim jest statek ponieważ jego ładownia nie jest magazynem materiałów niebezpiecznych W rozumieniu międzynarodowych przepisów morskich (IMDG Code 2014). Statek przeznaczony do transportu towarów niebezpiecznych musi posiadać ważny certyfikat określający miejsce oraz dopuszczalną ilość towarów niebezpiecznych (Document of Compliance for the Carriage of Dangerous Goods) według zaleceń SOLAS. 
W związku z tym, iż Raport Konwencji MARCOM 73/78 przyjmuje do obliczeń przepisy niemieckie, w konkretnym przypadku zastosowano równoważne obliczenia zgodnie z polskim prawem.

Zasady transportu materiałów niebezpiecznych zostały też unormowane ustawą z dnia 19 sierpnia 2011 r. o przewozie towarów niebezpiecznych oraz w aktach wykonawczych do tej ustawy.

Zgodnie z klasyfikacją IMO zawartą w Międzynarodowym Morskim Kodeksie Ładunków Niebezpiecznych (kodeks IMDG - IMO - PRS, Polski Rejestr Statków), materiały

i przedmioty wybuchowe dzielą się na następujące klasy i podklasy, które zostały scharakteryzowane jak niżej:

1. Klasa 1 - Materiały i przedmioty wybuchowe:

a) podklasa 1.1. - Materiały i przedmioty zdolne do wybuchu w masie,

b) podklasa 1.2. - Materiały i przedmioty stwarzające zagrożenie rozrzutu, lecz bez zdolności wybuchu w masie,

c) podklasa 1.3.- Materiały i przedmioty, które stwarzają zagrożenie pożarowe oraz małego wybuchu względnie małego rozrzutu albo obie te właściwości łącznie, lecz nie stwarzające zagrożenia wybuchu w masie. Podklasa ta obejmuje następujące materiały i przedmioty dające znaczne promieniowanie cieplne lub zapalające się jedno od drugiego z wystąpieniem małych wybuchów względnie niewielkiego rozrzutu lub obu tych zjawisk,

d) podklasa 1.4. - Materiały i przedmioty nie stwarzające poważniejeszego zagrożenia. Podklasa ta obejmuje materiały i przedmioty stwarzające tylko małe zagrożenie w przypadku zapalenia się lub zainicjowania wybuchu podczas transportu. Efekty są w większości ograniczone do opakowania i nie ma rozrzutu fragmentów o większym rozmiarze lub większym zasięgu. Ogień działający z zewnątrz nie powoduje praktycznie natychmiastowej eksplozji faktycznie całej zawartości opakowania,

e) podklasa 1.5. - Materiały i przedmioty bardzo mało wrażliwe, które przedstawiają niebezpieczeństwo wybuchu $\mathrm{w}$ masie. Podklasa ta obejmuje materiały i przedmioty wybuchowe, które są tak mało wrażliwe, że istnieje bardzo małe prawdopodobieństwo zainicjowania wybuchu lub przejścia od palenia się do wybuchu w normalnych warunkach przewozu. Minimalnym wymaganiem jest, że nie mogą one eksplodować w próbie ogniowej pochodzenia zewnętrznego,

f) podklasa 1.6. - Pozostałe materiały i przedmioty wyjątkowo niewrażliwe, które nie przedstawiają zagrożenia wybuchu $\mathrm{W}$ masie. Podklasa ta obejmuje materiały i przedmioty wybuchowe, które są wyjątkowo niewrażliwe i przedstawiają niewielkie ryzyko zainicjowania wybuchu.

Pośród omawianych przepisów skorzystano tylko z tych, które odnosiły się do sposobu ustalenia promienia stref zagrożenia w zależności od ukształtowania terenu, ilości materiału i zaklasyfikowania znajdujących się w strefie pośredniej budynków i obiektów. Jako kryterium do wyznaczenia stref bezpieczeństwa dla różnych obiektów przyjęto dopuszczalną wielkość nadciśnienia $\mathrm{w}$ fali uderzeniowej [5].

Nadciśnienie fali uderzeniowej zostało wyliczone ze wzoru zamieszczonego w Obwieszczeniu Ministra Rozwoju z dnia 22 stycznia 2016 r. w sprawie ogłoszenia jednolitego tekstu rozporządzenia Ministra Gospodarki, Pracy i Polityki Społecznej w sprawie bezpieczeństwa i higieny pracy przy produkcji, transporcie wewnątrzzakładowym oraz obrocie materiałów wybuchowych, w tym wyrobów pirotechnicznych.

Nadciśnienie fali uderzeniowej $\left(\mathrm{P}_{\mathrm{f}}\right)$ jako funkcję odległości czoła fali $(\mathrm{L})$ od miejsca wybuchu materiału wybuchowego i jego równoważnika heksogenowego (G) wyznacza się doświadczalnie w drodze badań modelowych lub określa według wzoru:

$$
\mathrm{P}_{\mathrm{f}}=980 \cdot\left(\mathrm{L} \cdot \mathrm{G}^{-1 / 3}\right)^{-1.89}
$$


gdzie poszczególne określenia oznaczają:

$\mathrm{P}_{\mathrm{f}}$ - nadciśnienie fali uderzeniowej $\mathrm{w} \mathrm{kPa}$,

$\mathrm{L}$ - odległość od miejsca wybuchu w metrach.

Poszczególne strefy zagrożenia po wybuchu, posiadają kształt pierścieni wyznaczonych liniami stałego ciśnienia fali uderzeniowej. W otoczeniu, w którym znajdują się materiały wybuchowe, podczas wybuchu których powstaje fala uderzeniowa, wyznacza się strefy zagrożenia wybuchem, które dzieli się ze względu na przewidywane nadciśnienie fali uderzeniowej na strefy:

a) bezpośrednią - nadciśnienie fali uderzeniowej ponad $250 \mathrm{kPa}$;

b) bliską - nadciśnienie fali uderzeniowej od 35 do $250 \mathrm{kPa}$;

c) pośrednią - nadciśnienie fali uderzeniowej od 5 do $35 \mathrm{kPa}$;

d) daleką - nadciśnienie fali uderzeniowej do $5 \mathrm{kPa}$.

Poniżej przedstawiono wartości nadciśnienia fali uderzeniowej i jej oddziaływanie na człowieka i otoczenie podczas wybuchu:

- $\quad \mathrm{Pf} \leq 2 \mathrm{kPa}\left[0,02 \mathrm{~kg} / \mathrm{cm}^{2}\right]$ - jest bezpieczne dla ludzi;

- $2 \mathrm{kPa}<\mathrm{Pf}<17,5 \mathrm{kPa}\left[0,175 \mathrm{~kg} / \mathrm{cm}^{2}\right]$ - powoduje uszkodzenie bębenków usznych;

- $17,5 \mathrm{kPa}<\mathrm{Pf}<40 \mathrm{kPa}\left[0,4 \mathrm{~kg} / \mathrm{cm}^{2}\right]$ - powoduje uszkodzenie układu oddechowego (płuc);

- $40 \mathrm{kPa}<\mathrm{Pf}<300 \mathrm{kPa}\left[3 \mathrm{~kg} / \mathrm{cm}^{2}\right]$ - powoduje poważne uszkodzenia organów wewnętrznych oraz zewnętrzne obrażenia ciała zależne od położenia w stosunku do kierunku rozchodzenia się fali uderzeniowej;

Jako kryterium do wyznaczenia stref bezpieczeństwa dla różnych obiektów przyjęto wg. tabeli 1 dopuszczalną wielkość nadciśnienia w fali uderzeniowej.

Tabela 1. Dopuszczalne wielkości nadciśnienia w fali uderzeniowej dla różnych obiektów.

\begin{tabular}{|c|l|c|}
\hline Lp. & $\begin{array}{c}\text { Rodzaj zagrożonego obiektu w stosunku do } \\
\text { którego jest wyznaczana bezpieczna odleglość }\end{array}$ & $\begin{array}{c}\text { Dopuszczalna wielkośćc } \\
\text { nadciśnienia fali } \\
\text { uderzeniowej }\left(\mathbf{P}_{\mathbf{f}}\right)\end{array}$ \\
\hline 1. & $\begin{array}{l}\text { Budynki produkcyjne i inne obiekty budowlane, } \\
\text { drogi, ogrodzenia zewnętrzne zakładu, } \\
\text { napowietrzne linie wysokiego napięcia }\end{array}$ & $5-35 \mathrm{kPa}$ \\
\hline 2. & Budynki mieszkalne - zabudowa rozproszona & $<5 \mathrm{kPa}$ \\
\hline 3. & Budynki mieszkalne - zabudowa zwarta & $<3 \mathrm{kPa}$ \\
\hline
\end{tabular}

Dla odległości 80 do 500 m obowiązuje wzór następujący:

$$
\mathrm{L}_{\mathrm{d}}=3,693 \times \mathrm{P}_{\mathrm{f}}^{-1} \times \mathrm{G}^{0,63}+27,1
$$

gdzie poszczególne określenia oznaczają:

$\mathrm{L}_{\mathrm{d}}$ oznacza odległość, od wagonów z ładunkiem niebezpiecznym klasy 1 na stanowisku przeładunkowym do obszaru chronionego, to jest do ogrodzenia portu.

$\mathrm{P}_{\mathrm{f}}$ - maksymalne nadciśnienie na czole fali detonacyjnej w $\mathrm{kPa}$ dla odległości $\mathrm{L}_{\mathrm{d}}$. 
Minimalną dopuszczalną odległość obiektów, w których znajduje się materiał wybuchowy, od innych obiektów wyznacza się doświadczalnie, w drodze badań modelowych lub określa według wzoru:

$$
\mathrm{L}_{\mathrm{d}}=38,25 \times \mathrm{P}_{\mathrm{f}}^{-0,529} \times \mathrm{G}^{1 / 3}
$$

gdzie poszczególne określenia oznaczają:

$\mathrm{L}_{\mathrm{d}}$ - minimalna dopuszczalna odległość w metrach,

$\mathrm{G}$ - równoważnik heksogenowy w kilogramach,

$\mathrm{P}_{\mathrm{f}}-$ dopuszczalne nadciśnienie fali uderzeniowej $\mathrm{w} \mathrm{kPa}$.

W przypadku konieczności szczegółowego wyliczenia zasięgu zaistnienia strefy nadciśnienia fali uderzeniowej podczas zagrożenia wybuchem oznaczonego w ilości i zidentyfikowanego materiału wybuchowego zawartego w kontenerze lub w kontenerach na terenie portu, należy posługiwać się ww. procedurą.

Wraz ze wzrostem odległości epicentrum wybuchu od miejsca pomiaru, nadciśnienie maleje. Dodatkowo przyjęte wartości jako bezpieczne dla ludzi i obiektów zmniejszają się o $50 \%$, jeżeli między wybuchem a obiektem występują elementy thumiące: konstrukcja kontenera, konstrukcja statku, przeszkody terenowe, konstrukcja obiektów budowlanych itp.

W przypadku konieczności szczegółowego wyliczenia zasięgu zaistnienia strefy nadciśnienia fali uderzeniowej podczas zagrożenia wybuchem oznaczonego w ilości i zidentyfikowanego materiału wybuchowego zawartego w kontenerze lub w kontenerach na terenie terminalu, należy posługiwać się procedurą zawartą w Załączniku nr 1 do Rozporządzenia Ministra Gospodarki, Pracy i Polityki Społecznej z dnia 09 lipca 2003r. w sprawie bezpieczeństwa i higieny pracy przy produkcji, magazynowaniu i transporcie wewnątrzzakładowym materiałów wybuchowych (Dz.U. 2016 poz. 262) [11].

\section{Zasady zapobiegania zagrożeniom}

$\mathrm{W}$ problematyce poruszanej $\mathrm{w}$ artykule przytoczono przede wszystkim elementy związane $\mathrm{z}$ zapobieganiem zagrożeniom przy przewozie materiałów wybuchowych. W przypadku awarii lub katastrofy będącej następstwem nieszczęśliwego wypadku, zachodzi realne zagrożenie ludzi i środowiska naturalnego. Wymagany sposób pakowania kontenera $\mathrm{z}$ materiałami wybuchowymi oraz wymagania segregacji tych materiałów podczas pakowania kontenera, w zależności od przypisanych im grup zgodności, przedstawia tabela - pkt. 7.2.7.2.1.4 Kodu IMDG [8].

Niebezpieczeństwo wybuchu podczas operacji przeładunku dotyczące kontenerów zawierających materiały wybuchowy istnieje wówczas, gdy nie są przestrzegane wymagania dotyczące prawidłowej i bezpiecznej obsługi. Ponieważ nie przewiduje się składowania materiałów wybuchowych „luzem”, konteneryzacja jest również czynnikiem powodującym zwiększenie bezpieczeństwa poprzez pewnego rodzaju odizolowanie materiału wybuchowego od zewnętrznych bodźców mogących zainicjować niekontrolowany proces wybuchu, a określona

w Kodzie IMDG segregacja materiałów wybuchowych oraz wymagania dotyczy bezpiecznej obsługi zapewniają wysoki stopień minimalizacji takiego ryzyka.

Niemniej należy się liczyć z faktem, że w przypadku niekorzystnych uwarunkowań technicznych i technologicznych, w wyniku błędów człowieka jak również zamierzonego działania człowieka takie zagrożenia może wystąpić. Dlatego też ważnymi są przygotowane procedury postępowania wszystkich zainteresowanych stron biorących udział w procesie przeładunku i obsługi materiałów wybuchowych na taką okoliczność.

Wszystkie operacje dotyczące załadunku, wyładunku i przeładunku dotyczą wszystkich opakowań i towarów niebezpiecznych, w tym wprowadzenia 
(i późniejszego usunięcia) każdego pojemnika, pojemnika zbiorczego, kontenera-cysterny lub cysterny przenośnej na pojeździe. Kontrole przed załadunkiem i transportem towarów niebezpiecznych muszą być przeprowadzane we wszystkich okolicznościach [9].

Nadzór nad przewozem towarów niebezpiecznych oraz nad jednostkami realizującymi zadania związane $\mathrm{z}$ tym przewozem sprawuje minister właściwy do spraw transportu. (z wyjątkiem przewozu materiałów niebezpiecznych środkami transportu należącymi do sił zbrojnych- gdzie nadzór sprawuje Minister Obrony Narodowej). W ramach sprawowanego nadzoru minister właściwy do spraw transportu w szczególności sprawdza prawidłowość: działań podejmowanych przez służby kontrolne (Inspekcja Transportu Drogowego); wykonywania przez Dyrektora TDT zadań w zakresie:

- prowadzenia ewidencji doradców,

- prowadzenia ewidencji podmiotów prowadzących kursy dla doradców,

- wydawania świadectwa doradcy i świadectwa dopuszczenia pojazdu ADR;

- czynności wykonywanych przez marszałka województwa w zakresie wydawania zaświadczeń ADR [7].

Znajomość przepisów i dobra organizacja przewozu zapewniają bezpieczeństwo w transporcie ładunków niebezpiecznych. Przede wszystkim niezbędne jest zakwalifikowanie przewożonego materiału do jednej Z wydzielonych klas towarów niebezpiecznych. W ten sposób można określić prawidłowe postępowanie $\mathrm{z}$ towarem $\mathrm{w}$ czasie jego przemieszczania i zastosować odpowiednie środki transportu. Obowiązek odpowiedniego przygotowania i wyposażenia pojazdu spoczywa na przewoźniku, natomiast załadowca powinien każdorazowo sprawdzić, czy rzeczywiście podstawiony środek transportowy spełnia wymagania stawiane danej klasie materiałów niebezpiecznych będącej przedmiotem przewozu. Przy organizacji przewozów materiałów niebezpiecznych należy zwrócić także szczególną uwagę na prace ładunkowe oraz dobór właściwej technologii prac ładunkowych. Niebagatelny wpływ na transport ładunków niebezpiecznych mają oczywiście osoby bezpośrednio związane $\mathrm{z}$ przewozami materiałów niebezpiecznych ( $\mathrm{tj}$. kierowcy). Od ich wiedzy o rodzaju przewożonego materiału, warunkach przewozu oraz sposobie postępowania $\mathrm{z}$ danym ładunkiem zależy w dużym stopniu bezpieczeństwo tego przewozu [8].

W tym zakresie istotne jest bezwzględne przestrzeganie przepisów o przeszkoleniu tych osób oraz o spełnianiu przez nie warunków określonych w przepisach prawnych.

\section{Podsumowanie}

Przeprowadzone badania pozwoliły na wypracowanie metody umożliwiającej rozwiązanie problemów $w$ poruszanych zagadnieniach tj. jest procedur związanych z zapobieganiem zagrożeniom przy przeładunku materiałów wybuchowych. Przeładunki tej grupy ladunków powinny odbywać się zgodnie z procesem technologicznym. Każdemu ładunkowi niebezpiecznemu musi towarzyszyć instrukcja postępowania w przypadku awarii, uwzględniająca specyficzne cechy ładunku lub grupy ładunków. Konieczne jest zapewnienie straży pożarnej i zespołom ratownictwa dogodnego dojazdu do miejsc przeładunku oraz dostępu do dokumentacji, i instrukcji przeładunku ładunków niebezpiecznych.

Otrzymane wyniki wskazują na potrzebę dogłębnego zbadania zagadnienia zasad organizacji operacji przeładunku kontenerów zawierających materiały wybuchowy, szczególnie wtedy, gdy nie są przestrzegane wymagania dotyczące prawidłowej i bezpiecznej obsługi. Konteneryzacja ww. ładunków jest czynnikiem powodującym zwiększenie bezpieczeństwa poprzez pewnego rodzaju odizolowanie materiału wybuchowego od zewnętrznych bodźców mogących zainicjować niekontrolowany proces wybuchu, a określona w Kodzie IMDG 
segregacja materiałów wybuchowych oraz wymagania dotyczy bezpiecznej obsługi zapewniają wysoki stopień minimalizacji takiego ryzyka.

Niezwykle istotnym czynnikiem warunkującym wysoki poziom bezpieczeństwa przewozów materiałów wybuchowych jest skoordynowana praca wykwalifikowanej kadry, dobra, niczym niezakłócona komunikacja o stanie ładunku w danej chwili.

W celu zminimalizowania ryzyka związanego z przewozem towarów niebezpiecznych, trzeba zwrócić uwagę na wszystkie jego elementy tak, aby były wykonywane rzetelnie

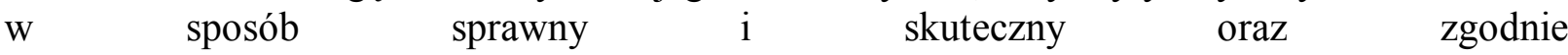
z obowiązującymi przepisami.

\section{Literatura}

[1] Baryłka A., Wprowadzenie do zagadnień problemów techniczno-prawnych eksploatacji obiektów budowlanych - Inżynieria Bezpieczeństwa Obiektów Antropogenicznych (1-2, 2019)

[2] Baryłka A., Issu of building structures necessary for the purposes of state security and defence in the provisions of the act - on spatial planning and development, Inżynieria Bezpieczeństwa Obiektów Antropogenicznych, nr 2/2017

[3] Biernikowicz W., Smal T., Nowe standardy bezpieczeństwa na rynku przewozów kontenerowych, [w:] Edukacja dla bezpieczeństwa, WSB 2008.

[4] Drewek W.: Kryteria i zasady wyboru trasy przewozu materiałów niebezpiecznych według międzynarodowej konwencji przewozu drogowego towarów i ładunków niebezpiecznych , Logistyka 5/2012.

[5] Chmieliński M., Bezpieczeństwo $w$ portach morskich o podstawowym znaczeniu dla gospodarki narodowej podczas przeładunku materiatów wybuchowych. Gdynia, Wydawnictwo BP, 2019.

[6] Pałucha K., Chmieliński M., Obsługa logistyczna i bezpieczeństwo transportu morskiego materiałów wybuchowych. X Międzynarodowa Konferencja Uzbrojeniowa „Naukowe aspekty techniki uzbrojenia i bezpieczeństwa” WAT 15-18.09.2014 r.

[7] Ustawa z dnia 21 marca 1991r. o obszarach morskich i administracji morskiej (tj. Dz. U.z 2013 r. poz. 934 ze zmianami).

[8] Ustawa z dnia 20 grudnia 1996r. o portach i przystaniach morskich (tj. Dz. U. z 2010 r. Nr 33, poz. 179).

[9] Ustawa z dnia 18 sierpnia 2011 r. o bezpieczeństwie morskim (Dz. U. Nr 228, poz. 1368, ze zmianami).

[10] Ustawa z dnia 19 sierpnia 2011 r. o przewozie towarów niebezpiecznych (Dz. U. $\mathrm{Nr}$ 227, poz. 1367 ze zmianami).

[11] Rozporzadzenie Ministra Transportu, Budownictwa $i$ Gospodarki Morskiej $z$ dnia 17 czerwca 2013 r. w sprawie określenia dodatkowych wymagań dotyczacych przewozu towarów niebezpiecznych statkami niepodlegającymi konwencji SOLAS (Dz. U. z 2013 r. poz. 798).

[12] Zarzadzenie Porzadkowe $\mathrm{Nr} 4$ Dyrektora Urzędu Morskiego w Gdyni z 7 sierpnia 2000 r. w sprawie zapobiegania powstawaniu i rozprzestrzenianiu się pożaru, klęski żywiołowej lub innego miejscowego zagrożenia na obszarze morskich portów i przystani (Dz. Urz. Województwa Pomorskiego Nr 108, poz. 705). 
[13] Zarzadzenie porzadkowe nr 5 Dyrektora Urzędu Morskiego w Gdyni z dnia 20 lutego 2013 r. Przepisy Portowe (Dz. Urz. Pomor. Poz. 1314).

[14] Rekomendacje dot. transportu materiatów niebezpiecznych oraz operacji zwiazanych $w$ portach. Aneks II - transport i obchodzenie się z ladunkami niebezpiecznymi k1.1 /IMO. MSC.Circ.675 z 09.12.1994r.

[15] Kodeks IMDG (International Maritime Dangerous Goods Code) - Międzynarodowy Morski Kodeks Międzynarodowej Organizacji Morskiej (IMO - International Maritime Organization), stanowiący załącznik do Międzynarodowej konwencji 1974, sporządzonej w Londynie dnia 1 listopada 1974 r. (Dz. U. z 1984 r. Nr 61, poz. 3181319 i 320, z 1986 r. Nr 35, poz. 177, z 2005 r. Nr 120, poz. 1016 oraz 22008 r. Nr 191, poz. 1173) wraz z Protokołem z 1978 r. dotyczącym Międzynarodowej konwencji o bezpieczeństwie życia na morzu, 1974, sporządzonym w Londynie dnia 17 lutego 1978 r. (Dz. U. z 1984 r. Nr 61, poz. 320 i 321), obwieszczenie Ministra Transportu, Budownictwa i Gospodarki Morskiej z dnia 9 października 2012 r. w sprawie podania do publicznej wiadomości niektórych przepisów międzynarodowych dotyczacych przewozu materiałów niebezpiecznych oraz ladunków masowych statkami morskimi (Dz. Urz. MTBiGM poz. 71).

[16] https://www.polskieradio.pl/42/273/Artykul/2030647,Rzad-stawia-na-polskie-porty-do2030-r-inwestycje-warte-25-mld-zl (dostęp 10.06.2019)

[17] http://www.gospodarkamorska.pl/Porty,Transport/polski-port-community-systemoddolnie-i-odgornie-budowany.html (dostęp 13.06.2019) 